\title{
THE PRIMITIVE NUMBER OF MALPIGHIAN VESSELS IN INSECTS.-V.
}

BY WILliaM MORTON WHEELER, PH.D., CIICAGO, ILL.

Neuroptera. Leon Dufour*, Frey and Leuckart†, v. Siebold $\ddagger$ and Schindler $\S$ have shown that members of this order have either 6 or 8 Malpighian vessels. The imaginal Sialis has 6 vessels and the same number of discrete proctodaeal diverticula is established in the embryo, as I have observed in $S$. infumata. In what I take to be the young larva of Corydalis cornuta there are also 6 vessels but in other much larger larvae (possibly belonging to the genus Chauliodes) I find the unusual number 7 . This insect, therefore, constitutes a transition to the forms with 8 vessels, such as Myrmeleon and Hemerobius.

Panorpata. The Scorpion flies (Panorpa) agree with Sialis in possessing 6 vessels.

Trichoptera. Patten $\|$ has shown that the embryo Neophylax concinnus develops 6 Malpighian vessels as discrete proctodaeal diverticula. This number seems to be retained throughout life by all the species of the order.

$$
\begin{aligned}
& \text { *1. c. p. } 565 \text {. } \\
& \text { †1. c. p. } 101 . \\
& \text { †l. c. p. } 627 \text {. } \\
& \text { §1. c. p. } 628 \text {. }
\end{aligned}
$$

\|The development of phryganids, with a preliminary note on the development of Blatta germanica. Quart. journ. micr. sci. vol. xxiv, 1884 , p. 590 .
Coleoptera. Schindler* makes the following general statement in regard to this order : "Vier Malpighi'sche gefässe finden sich durchgehends bei den Pentameren, wogegen den Heteromeren, Tetrameren und Trimeren stets sechs zukommen." This assertion ap. pears to require some qualification, since the Pentameron Hydrophilus has 6 Malpighian vessels according to Vangel $\dagger$ while the Heteromeron Sitaris has only 4 according to Beauregard. $\ddagger$

These are very briefly the facts derived from a study of the embryo: in the greater number of forms the vessels arise as 6 discrete diverticula of the hind-gut. This has been shown for Doryphora by myselfs, for Melolontha by Voeltzkow $\|$ and for Hydrophilus by Heider. $\uparrow$ In the embryo

\footnotetext{
* 1. c. p. 629 (foot note).
}

† Beiträge zur anatomie, histologie u. physiologie des verdauungsapparates des wasserkäfers (Hydrophilus piceus, L.) Nat. hefte. Pest. bd. 10, 1886.

$\ddagger$ Recherches sur les insectes vésicants. i partie, anatomie. Journ, anat. phys. Paris. 21. Annee 18851886.

$\S$ The embryology of Blatta germanica and Doryphora decem.lineata. Journ. morph. vol. iii, no. 2. I889.

\|Melolontha vulgaris. Ein beitrag zur entwickelung im ei der insecten. Arb. a. d. zool. zoot. inst. in Wiirzb. bd. ix. heft 1. 1889. (Plate v. figs I, 2 \& I3.)

IT Die embryonalentwicklung v. Hydrophilus piceus, L i. theil. Jena. is89. 
Dytiscus fasciventris I find only 4 vessels, and this number is retained in the imago.

Melolontha vulgaris deserves special mention, as it shows that the tetranephric is a modification of the hexanephric condition. Voeltzkow, as I have said, found 6 Malpighian vessels in the embryo of this Scarabaeid, whereas writers on the adult and larva describe only 4. A pair of vessels must, therefore, be suppressed during post-embryonic development, presumably in early larval life. The bearing of this fact on the tetranephric condition of Dytiscus is obvious; we have only to suppose that the tendency to suppress a pair of vessels has been carried back into early embryonic life.

Lepidoptera. Schindler * and Cholodkowsky + have given us a considerable body of facts on the number and disposition of the Malpighian vessels in the Lepidoptera. The embryonic development of the tubules was elucidated by Hatschek ${ }_{+}$, as long ago as 1877 . "Wir finden" says this investigator, "im stadium $\mathrm{C}$ schon 6 Malpighi'sche drüsen, jederseits drei, die nach hinten zurückgebogen, rings um den hinterdarm auf dem querschnitte sich zeigen (figs. 3 and 4 , pl. iii). Die drei Malpighi'schen drüsen jeder seite münden durch ein gemeinschaftliches aufangsstück in das blinde ende des hinterdarmes." Hatschek's figures show the arrangement of the

*1. c. p, 646 et seq.

$\dagger$ 1. c.

$\ddagger$ Beiträge zur entwicklungsgeschichte der Lepi dopteren. Naumburg, 1877, p. 19 . vessels to be the same as in the larva and imago. My own observations on embryos of Platysamia cecropia confirm his account.

With the exception of a very few species, to be considered presently, all Lepidoptera have 6 Malpighian vessels. They are not discrete diverticula of the hind-gut, but on either side two of the vessels are united by a common trunk to the third, so that there is only one opening into the rectum on either side. This antler-like system appears to arise in the following manner : a hollow bud grows out from the proctodaeum and bifurcates; then one of the two vessels thus formed bifurcates, while the other simply lengthens. Cholodkowsky calls the duct leading into the rectum the "tronc basilaire," the one uniting the two terminal vessels the "tronc secondaire." He gives an extended account of the relative variations in length of the two trunks throughout the various families of Lepidoptera. The variations are sometimes considerable, but the number 6 is rigorously adhered to. The only exceptions observed by Cholodkowsky are the Pyralid Galleria and certain Tineids.

In G. melonella the Malpighian vessels resemble two trees "richement et irrégulièrement ramifiés." 'This peculiar form is so strikingly unique that we may put it down without hesitation as a secondary development. Cholodkowsky finds that the larva of Tinea biselliella has the typical 6 Malpighian vessels; but these break down during the pupal stage and in their stead arises 
a single pair of imaginal tubules. The Russian investigator has established the same interesting fact for Tinea pellionella and Blabophanes rusticella.

On these cases, avowedly exceptional even among Tineidæ, Cholodkowsky bases his dinephric hypothesis. The return in the imago to an apparently simpler condition of the Malpighian vessels than obtains in the larva, is regarded by him as a kind of atavism. To characterize this form of reversion, which is regular and periodic in its occurrence, he introduces the term "atavisme périodique." But it is clear that this atavism, if atavism it be, must extend to ancestral conditions exceedingly remote-postulating 2 as the primitive number of Malpighian tubules in Arthropods-since the number 2 occurs only in verv few insects, and only in cases where a secondary reduction from a greater number furnishes a more plausible explanation (Coccidae).

Cholodkowsky assumes that the basal trunk represents the primitive Malpighian vessel. I would regard both it and the secondary trunk as comparatively recent acquisitions, since I find it difficult to see, on Cholodkowsky's supposition, why the number of vessels should be so constant throughout the order and at the same time agree with the number observed in the older and more primitive orders (Orthoptera, Neuroptera, Panorpata). Moreover, it is generally admitted that the Trichoptera stand very near the hypothetical ancestral Lepidopter, and it has been shown that both the embryo and imaginal Trichopter have 6 discrete Malpighian tubules. On Cholodkowsky's supposition it would be necessary to regard the urinary vessels in the lower orders as less primitive than those of the Lepidoptera, an assumption which certainly has very little in its favor when we stop to consider the extent to which other organs have been modified in the Lepidoptera.
Entomological Notes. - The 1 3 th part of Kolbe's Einführung in die kenntnis der insekten completes the first volume of the work, and with it the account of the morphology and physiology of insects; it concludes with a bibliography of the organs of generation. Although only two of the twelve main divisions contemplated have been treated, another volume will doubtless complete the work.

In the Contemporary review for September, Weismann has a deeply interesting article on the All-sufficiency of natural selection, supporting his well known views of the intransmissibility of acquired characters, and in which his main arguments are drawn from the study of ants. "All-sufficiency" is a strong term, and if it were generally con- ceded would prove a distinct bar to progress; working hypotheses, on the other hand, lie at its very foundation.

In recent information regarding the Cambridge botanic garden given in the last number of the Harvard graduates magazine, Prof. G. L. Goodale speaks of the damage done by white ants as follows: "In one part of the wall the ants had taken away nearly all the wood, leaving the painted surface untouched and apparently sound. From this wall they had made their way into floor timbers hitherto supposed to be free from any pest."

Mr. Townsend (Ins. life, 5: 317) identifies the oestrid larva described by him in the current volume of Psyche, p. 298, as Cuterebra fontinella Clark. 

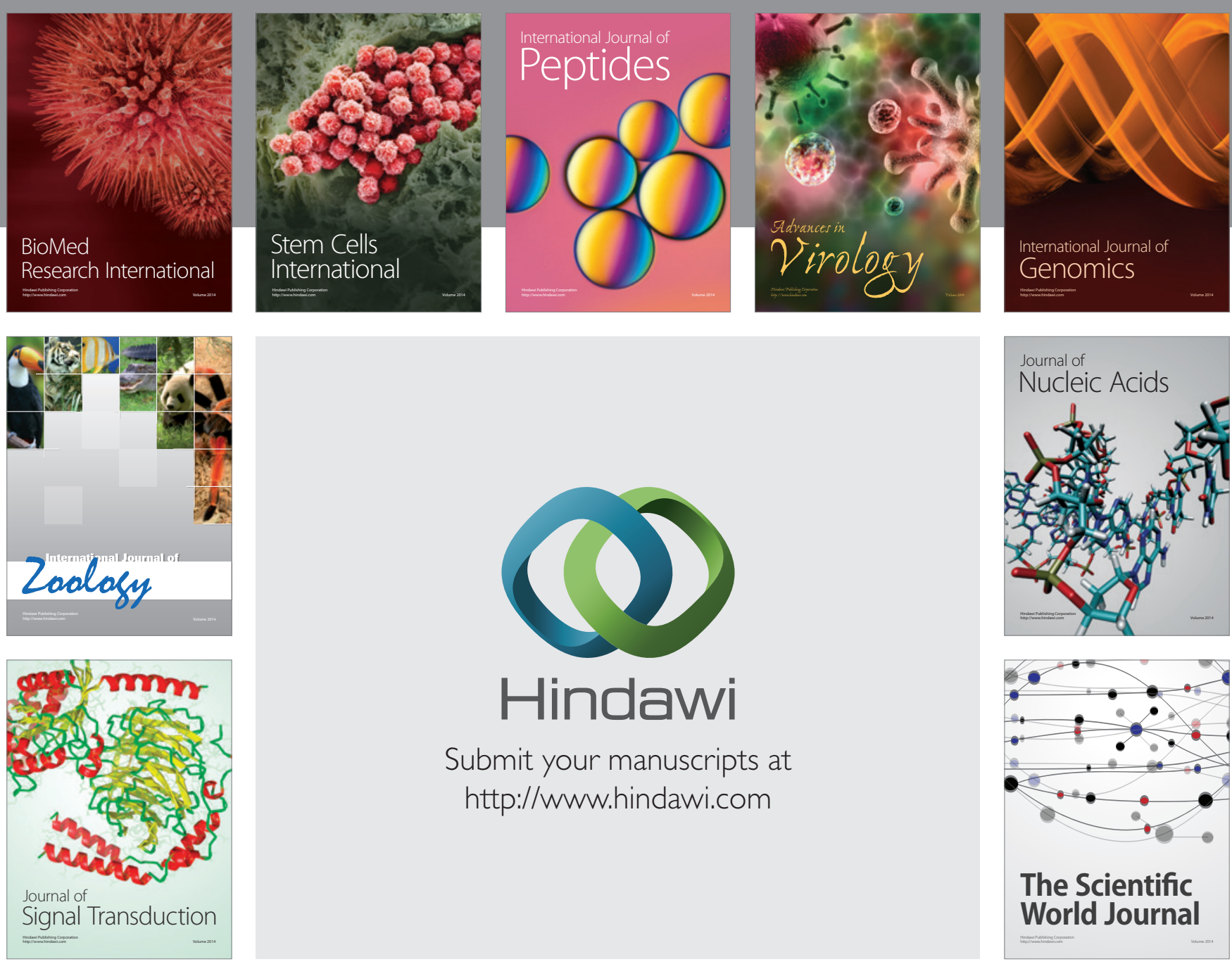

Submit your manuscripts at

http://www.hindawi.com
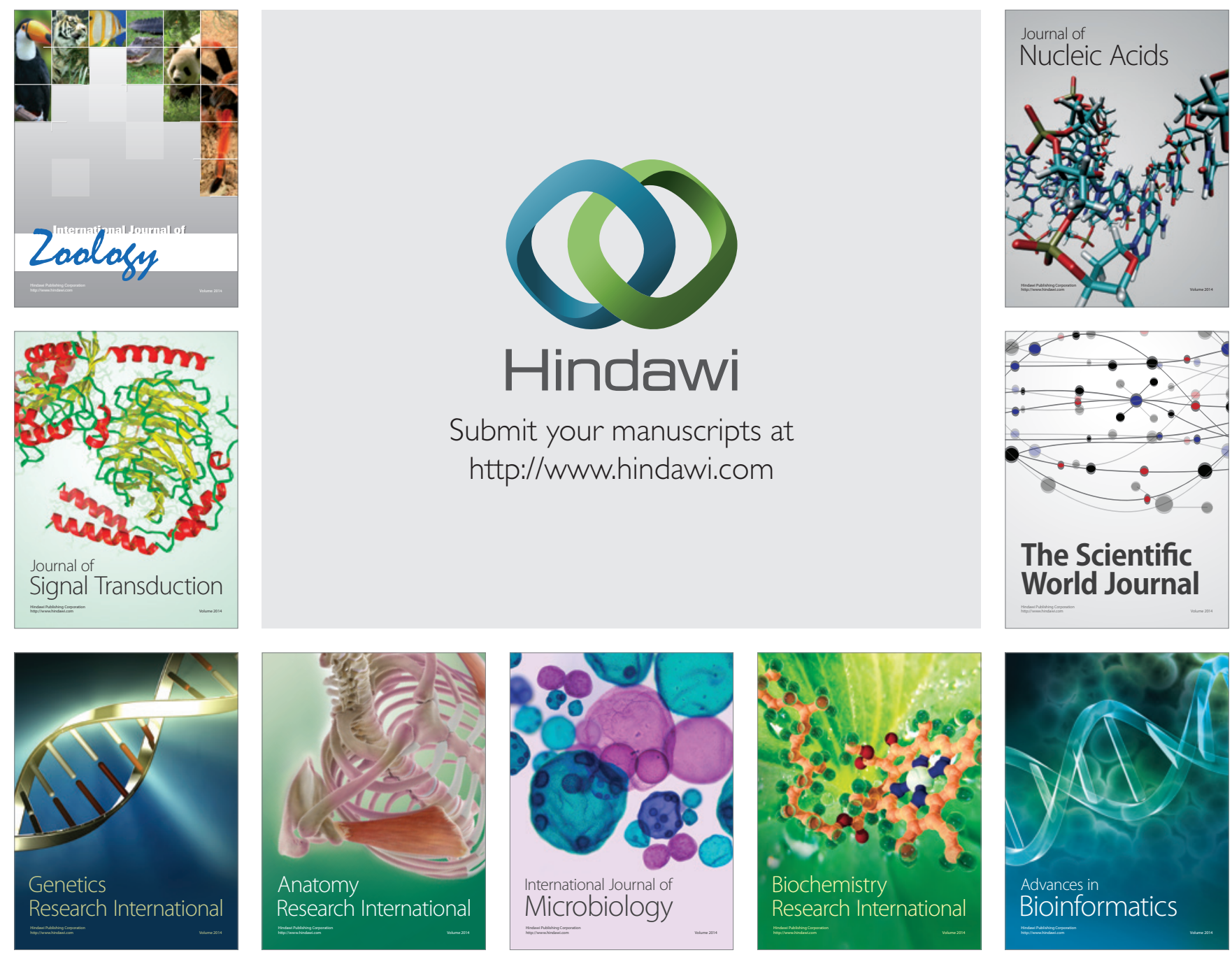

The Scientific World Journal
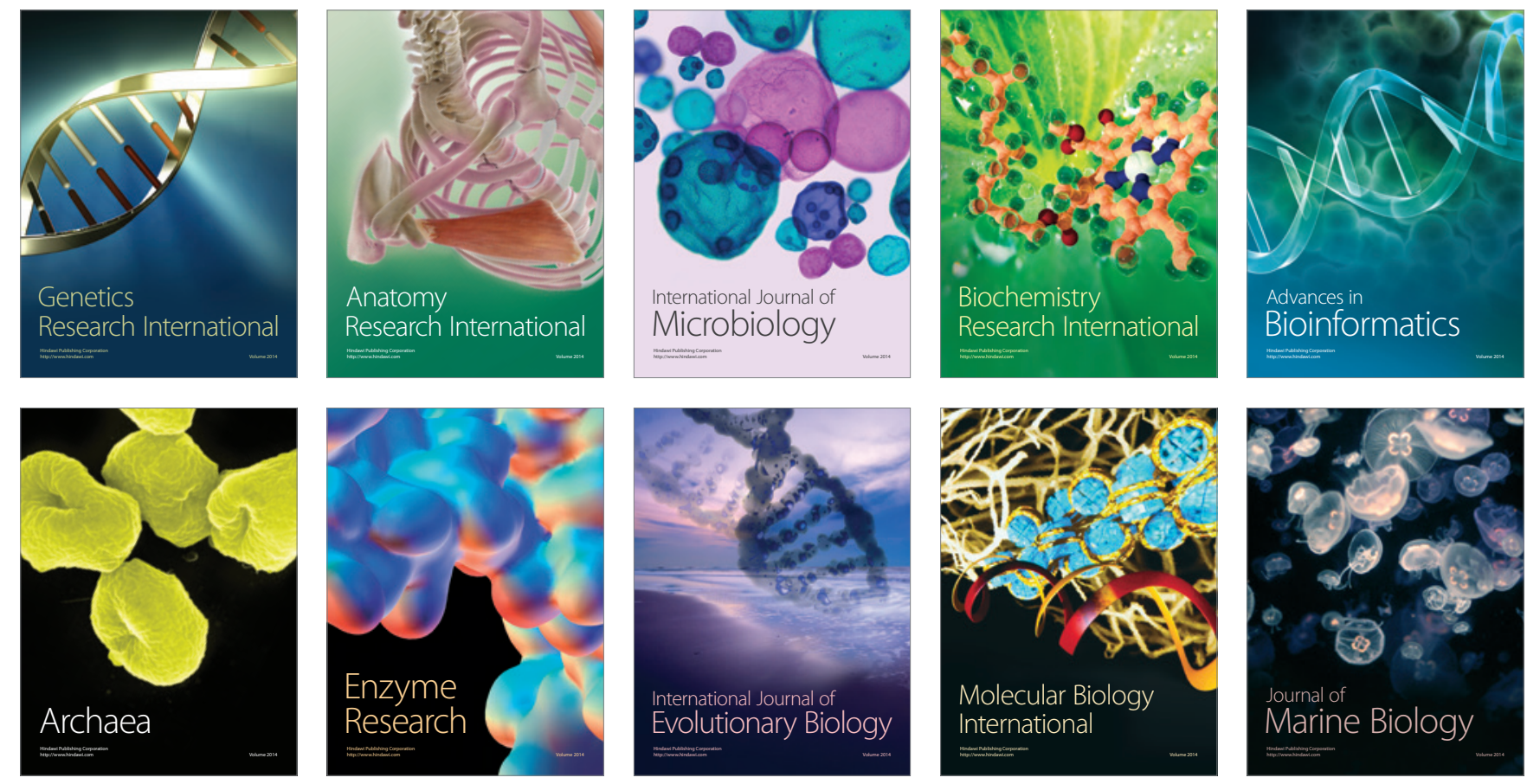